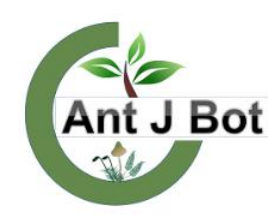

Received : 31.01 .2020 Accepted : 25.02.2020 Online : $: 31.03 .2020$

\title{
Dieffenbachia plant poisoning cases and effects on human health
}

\begin{abstract}
Many plants, such as Dieffenbachia Schott, which are poisonous and can be life threatening, are present in the habitats of people. Dieffenbachia is widely used for ornamental purposes in living quarters, but it is a plant species that can harm human health as a result of contact, chewing or ingestion. The aim of this work is to attract the attention of researchers to the role of the Dieffenbachia plant, often used for ornamental purposes in homes, especially in the case of home accidents that children are exposed to and the likelihood of abuse. For this reason, Dieffenbachia poisoning cases in the literature have been discussed in the context of resources. A total of 7 cases were studied, including three cases of 1-3 years of age, 3 cases of 7-12 years and a case of adult age of 69, obtained by investigating the literature. Dieffenbachia plant can cause vital signs, such as airway obstruction and respiratory failure, as well as mild skin reactions, depending on the type of contact and amount of exposure. Care should be taken and caution should be exercised on the use of plants such as Dieffenbachia and similar plants in houses, playgrounds and other green area regulations.
\end{abstract}

Key words: Dieffenbachia, toxic plants, child poisoning

Özet: Dieffenbachia Schott gibi zehirli etkisi olan ve yaşamı tehdit edebilen birçok bitki bilerek ya da bilmeyerek insanların yaşam alanlarında bulunmaktadır. Dieffenbachia, yaşam alanı olan evlerde süs amacıyla yaygın olarak kullanılmaktadır, ancak temas edilmesi, çiğnenmesi ya da yutulması sonucunda insan sağlığına zarar verebilen bir bitki türüdür. Bu çalışmanın amacı, evlerde sıklıkla süs amacıyla kullanılan Dieffenbachia bitkisinin, özellikle çocukların maruz kaldığı ev kazalarındaki rolü ve kötüye kullanım ihtimaline karşı araştırmacıların dikkatini çekmektir. Bu sebeple literatürde bulunan Dieffenbachia zehirlenmesi olguları kaynaklar çerçevesinde tartışılmıştır. Literatür taranarak elde edilen 1-3 yaş arası üç vaka, 7-12 yaș arası 3 vaka ve 69 yaş bir yetişkin vakası olmak üzere toplam 7 olgu ele alınmıştır. Dieffenbachia bitkisi, temas şekli ve maruz kalma miktarına bağlı olarak hafif cilt reaksiyonlarının yanı sıra havayolu tıkanıklığı ve solunum yetmezliğine kadar giden hayati bulgulara neden olabilmektedir. Evler, çocuk oyun alanları ve diğer yeşil alan düzenlemelerinde Dieffenbachia ve benzer özellikteki bitkilerin kullanımı konusunda dikkatli olunmalı ve gerekli tedbirler alınmalıdır.

Anahtar Kelimeler: Dieffenbachia, zehirli bitkiler, çocuk zehirlenmeleri

Citation: Ünlü Ü, Kocabaş A (2020). Dieffenbachia plant poisoning cases and effects on human health. Anatolian Journal of Botany 4(1): $65-68$.

\section{Introduction}

Humans have benefited from plants for different purposes for nearly 50,000 years (Özbek, 2005). People have used the plants obtained from nature in fields such as medicine, medicine industry, cosmetics, perfume, soap, essence, toothpaste, soft drinks, confectionery, healing and relaxing tea production, painting, ornament and landscape in houses (Sicak et al., 2013; Gül, 2014). Instinctively, they have learned which plants are poisonous or healing through trial and error. (Faydaoğlu and Sürücüoğlu, 2013; Yılmaz et al., 2006). Research shows that there are about 200 poisonous plants that can threaten human and animal health in Turkey (Yilmaz et al., 2006).

When consumed, plants that contain toxic substances that can result in death or disease for humans and animals are called "Poisonous Plants". Poisonous plants have always attracted the attention of people and tried to classify the poisons and medicines obtained from such plants (Balabanlı et al., 2006; Y1lmaz et al., 2006). There are many species and types of poisonous substances from different families. Alcohols, phytotoxins, oxalates, and resins are some toxic substances that are the result of plant metabolism. While the dose and quality of the poison vary according to the living species, they cause poisoning when they are taken into the body (Balabanlı et al., 2006; Y1lmaz et al., 2006; Y1lmaz et al., 2007). Aesculus hippocastanum L. (Horse chestnut), Brassica nigra L. (Black mustard), Lantana camara L. (Mine flower), Laurus nobilis L. (Laurel), Caesalpinia gilliesii Benth. (Peacock flower), Hedera helix L. (Wallflower), Nerium oleander L. (Oleander), Atropa belladonna L. (Belladonna), Colchicum speciosum Steven (Crocus) and Dieffenbachia picta Schott (crying flower), Rhus radicans L. (Poison ivy) are plants having toxic leaf and fruit (Balabanlı et al., 2006; Y1lmaz et al., 2006).

Dieffenbachia (Figure 1) plants belong to the family Araceae and naturally grow in tropical regions (Dip et al., 2004; Şişmanlar et al., 2010; Porsuk et al., 2014). These flowers, which are imported to Turkey, are often preferred for decoration in homes because they are grown easily, grow fast and like the shade environments (Akpinar et al., 2016). It is called "crying flower" among the people and can cause poisoning (Akpinar et al., 2016). Particularly the colorful leaves are attractive to children (Barnes and Fox, 1955). Dieffenbachia poisonings can manifest themselves in systemic or local effects in humans and animals (Akpınar et al., 2016). Vigorous clinical findings such as airway obstruction and respiratory insufficiency can occur with mild findings such as swelling, burning and pain in the 

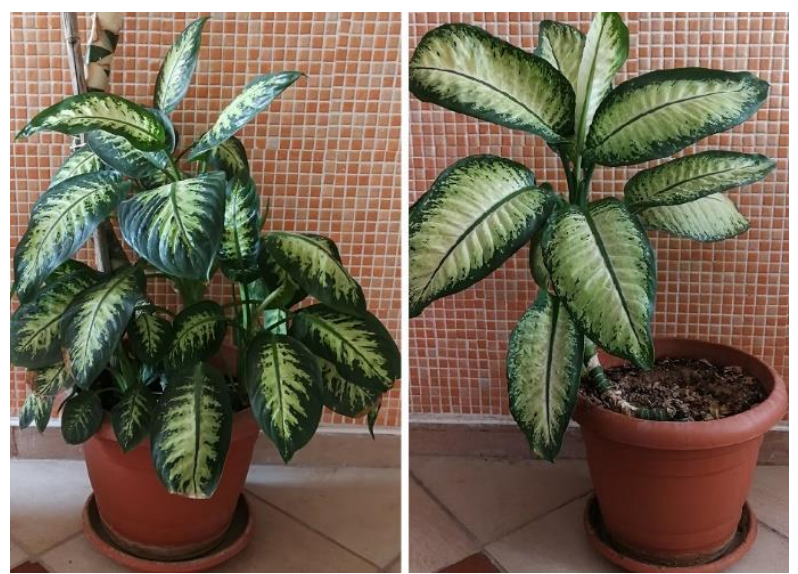

Figure 1. Dieffenbachia plants.

tongue and lips with the chewing of this plant (Dip et al., 2004; Şişmanlar et al., 2010).

The aim of this work is to attract the attention of researchers to the role of the Dieffenbachia plant, often used for ornamental purposes in homes, especially in the case of home accidents that children are exposed to and the likelihood of abuse. For this reason, Dieffenbachia poisoning cases in the literature have been compiled and discussed in the context of resources. A total of 7 cases, including three cases of 1-3 years, three cases of 7-12 years and a case of adults of 69 years, were obtained by searching the literature.

\section{Case Studies from Literature}

It is stated that two children aged between 1-3 years of age chew this plant by taking it to the mouth and that one of them was exposed to the grape juice which was transmitted to the hand because the bite of the plant was not bite (Şişmanlar et al., 2010; Akça et al., 2014; Porsuk et al., 2014). In the case reported by Şişmanlar et al. (2010), a 3year-old boy was brought to the Pediatric Emergency Service with difficulty in breathing, swelling of the tongue and lips. Half an hour before the complaint of the child's clinical trait emerged, it was found that the house chewed the plant named Dieffenbachia, the ornamental plant. After half an hour, there was an increase in the amount of mouth saliva, swelling of the mouth and lips. The findings of life were normal and there was no foreign body aspiration on the chest $\mathrm{x}$-ray. It has been seen that the patient has edema in his tongue and lips, breathing by opening his mouth, and having difficulty speaking a few words. Antihistamine and steroid treatment were given and the patient was discharged after 4 hours of observation and follow-up (Şişmanlar et al., 2010). According to Akça et al. (2014) a 23-month-old male patient with no history of disease was admitted to the hospital with complaints of swelling and redness on his lips. In the story of the patient, it was determined that a piece of Dieffenbachia plant, which is present in the house, was chewed by taking the leaf in her mouth and the complaints that emerged later appeared. It is stated that the complaints were brought to the hospital 2 hours after the emergence of the complaints. The patient was kept under observation for 24 hours and discharged because of complaints (Akça et al., 2014). In the case reported by Porsuk et al. (2014), A 25month-old male infant was crying and crying and was noticed by the family that the home-grown Dieffenbachia plant was broken. Since there is no trace of bite in the plant, it has been thought that the juice of the louse is licked or the juice of the infected water is drained. The family was referred to the hospital emergency department within 15 minutes. The National Poison Counseling Center (UZEM) for hospital consultation and the treatment recommended by UZEM have been applied. No complications occurred in the patient and the patient was discharged (Porsuk et al., 2014).

There are different symptoms in spite of the fact that oral exposure is seen in all cases. While there was difficulty breathing and edema when exposed to the rub, only the juvenile licking child had no significant symptoms. Besides, the time to reach the hospital after exposure is stated as 15 minutes, 30 minutes and 2 hours. The child brought to the hospital at the end of 2 hours has swelling and redness on the lips, and there is no obvious symptom in the child brought to the hospital in 15 minutes. Early treatment of the disease is thought to reduce complaints. However, compared to other cases, the child brought to the hospital after 30 minutes has more severe symptoms such as difficulty in breathing, tongue and swelling in the mouth. This can be related to the amount of chewing gum in the mouth and the length of the chewing time. The difference in symptoms can be due to the elapsed time in the patient's hospitilization and the exposure patterns.

When three cases between 7 and 12 years of age were examined, it was found that a 7-year-old boy bruised and smelled Dieffenbachia planta by hand, (Akpınar et al., 2016), a 9-year-old boy chews the leaf of the plant (Adhikari, 2012) and it is stated that the 12-year-old female patient consumed the plant leaf (Sinajdaufa et al., 2005). In the case presented by Akpinar et al. (2016) a boy who is 7 years old and has no known illness stories is referred to the hospital with urticaria findings (swelling, redness in the hands, itching and burning in the whole body) as a result of hand rubbing and smelling of Dieffenbachia plant. It was determined that the findings of life were normal, physical examination revealed urticarial plaques on the whole body. After the treatment, the patient was discharged (Akpinar et al., 2016). In the work done by Adhikari (2012) a 9-yearold boy has been admitted to the emergency room with irritation, pain, difficulty swallowing and salivation in the mouth. It was mentioned that the child chewed the leaf of a plant while playing in the park by the family of the child and the family brought the plant emergency service. Severe pain in the upper abdomen, erythema in the mouth and throat were detected in the physical examination. The patient's treatment started and at the end of 3 days the swelling and redness on the back decreased, the abdominal pain decreased and the liquid diet started to feed. The patient was discharged at the end of 4 days (Adhikari, 2012). In a phenomenon conveyed by Sinajdaufa et al. (2005) a 12-year-old female patient consumed the leaf of Dieffenbachia plant at home for suicide and applied to the emergency service after 6 hours. Parts of the plant were removed by washing with stomach lavage, but esophagitis was detected on the endoscope. After 14 days of treatment, the patient was referred to the hospital with bloody stool and bloody vomiting after 2 days. After the examinations, a $3 \mathrm{~mm}$ wide fistula was found between the patient's chest, food tube and aorta and necessary treatments were applied. The aorta-esophageal fistula could be detected five weeks after the procedure. Seven years after the patient's normal swallowing function has come and is not sequelae (Sinajdaufa et al., 2005). 
When examined, the patterns of exposure and symptoms are different. Only smell and contact with urticaria were seen, resulting in both severe symptoms and late complications. The plant was eaten abundantly for suicide purposes and the patient was brought to the hospital six hours after consumption. Both the amount of plant exposed and the duration of exposure are prolonged. It is also thought to be more fragmented and more active substance released because it is deliberately chewed. Especially late complications are related to late arrival and abundant consumption.

When a 69-year-old adult case is examined, it is seen that Dieffenbachia plant is taken orally. A 69-year-old male patient with asthma and pericarditis was admitted to the hospital with complaints of dysphagia, salivation and glossitis. Thirty minutes before his hospitilization, the patient thought that he was eating sugarcane and he ate Dieffenbachia plant but he spit it out without swallowing. The life of the patient was normal but lip, soft palate, uvula, laryngeal edema and, epiglottic enlargement were detected. The speech is expressed as muffled but understandable. Despite the initial treatment of the patient, the dyspnea increased after 1 hour and the patient had to open the tracheostomy. A chest tube was applied to treat the resulting lung injury. Oropharyngeal swelling gradually decreased within 3 days and after the treatment, tracheostomy and chest tube were terminated (Cumpston et al., 2003).

There was no adult case that could be compared with this case in the literature review. It is seen that the symptoms are less in the case of the child who is exposed to the same period and brought to the hospital in the same time period compared with the examined child cases and the severity of the dyspnea complaint is increased. Tracheostomy due to increased dyspnea had to be opened and a chest tube was applied. More severe complaints may be associated with older age and existing chronic diseases.

\section{Discussions}

In the 2006 toxic substance exposure report of the US Toxic Substances Control Center, 44710 of the 64236 cases related to interacting with plants are composed of children under the age of five (Akpinar et al., 2016). Only 4.9\% of the 61 patients who received Dieffenbachia orally according to the local poison counseling center reported symptoms in the first five minutes and symptoms were resolved with minimal supportive care. Poisoning treatment varies according to the clinical condition of the patient. Cold applications such as intubation or tracheostomy may be needed to provide antihistamines, steroid drugs and airway remodeling in severe cases, while cold application and pain relievers are sufficient for mild cases (Şişmanlar et al., 2010).

The homeland of the Dieffenbachia plant is tropical America and is known as the most poisonous among the plants imported to Turkey. This property has been used for various purposes since ancient times. The Tucuna Indians who lived in the Amazon used it as an arrow poison, on the slaves of Western Indians for torture. In order to prevent the conversation, the plant sap was brought to the grave and the slaves were punished. Brazilian Indians have added the poison of this plant to food, in anticipation that their enemies will prevent their reproductive ability (Barnes and Fox, 1955; Şişmanlar et al., 2010).

The mechanism of toxic effect in cases of poisoning with Dieffenbachia plant is not fully known. Calcium oxalate crystals, oxalic acid and protease are thought to be effective (Gardner, 1994; Akpınar et al., 2016; Akça et al., 2014). In the cells of the plant, needle-shaped calcium oxalate crystals are present intensively and the plants are protected against herbivores (Cote, 2009; Adhikari, 2012; Akpınar et al., 2016). Calcium oxalate crystals and proteolytic enzymes that are present in the leaves in the event of the plant's rubbing, rupturing or chewing cause inflammation, local irritation and tissue damage (Şişmanlar et al., 2010; Porsuk et al., 2014).

If the Dieffenbachia plant is carelessly battered, thousands of crystal arrows on the leaves and stems can spurt and cause some injuries, especially in the eyes (Akpinar et al., 2016). In case of contact with the eye, serious pain, chemosis (conjunctiva edema), blepharospasm, photophobia, lacrimation, corneal abrasion and keratoconjunctivitis occur (Şişmanlar et al., 2010; Porsuk et al., 2014). In one study, three cases were reported with characterization of pain and blurred vision after Dieffenbachia's blooming contact. The complaints of the patients started within 5-18 hours after admission and were fully recovered within one week after treatment (Hsueh et al., 2004). In a study performed on the albino rabbits, it was determined that the juice of the plant suffers damage to the conjunctiva and the cornea when dropped (Fochtman et al., 1969). In contact with the skin, mild dermatitis can cause symptoms to severe burns (Şişmanlar et al., 2010; Porsuk et al., 2014). If the leaves are chewed, the crystals will cause a burning sensation in the mouth and throat, and if they are swallowed, they will cause a temporary disability (Porsuk et al., 2014; Akpınar et al., 2016). In a study it was reported that Dieffenbachia prevented talking, that a criminal drove eyewitnesses into the mouth and that witnesses could not testify (Barnes and Fox, 1955). If ingested by mouth, pain, edema, increase in mouth secretions, ulceration, vomiting, diarrhea and swallowing difficulty can be seen (Gardner, 1994; Cumpston et al., 2003; Şişmanlar et al., 2010; Porsuk et al., 2014; T.C. Sağlık Bakanlığı, 2007). In addition, as a result of the ingestion of leaves, death due to acute airway edema is observed and it is known that this plant was used to punish prisoners in olden days (Akpinar et al., 2016). When different animal studies are examined, it can be seen that when the leaves of this plant are taken orally (Müller et al., 1998), it is also stated that a dog has dysphagia and airway obstruction (Peterson et al., 2009; Akça et al., 2014). In another study, it was stated that the dog, breaking the plant roots, had locally wide ulcerative glossitis and severe respiratory distress and that the dog had died despite the treatment (Loretti et al., 2003). In a study on mice, it was determined that the juice dropped on the mouth was similar to the reactions in the human body (Fochtman et al., 1969).

As a result, this plant, which has many harmful effects on human health and used for torture and punishment, is in our homes for decoration purposes. In addition to mild effects on health, studies with serious effects have been shown. Especially in the home environment where children can easily reach, children are at risk. It is considered that parents are able to be aware of this issue and to prevent possible risks by making the home environment safe. Information on the poisoning rate, effects and toxic parts 
should be provided by the businesses to which the sale is made in order to raise awareness of the user on the plant. Care should be taken and caution should be exercised on the use of plants such as Dieffenbachia and similar plants in houses, playgrounds and other green area regulations.

\section{References}

Adhikari KM (2012). Poisoning due to accidental ingestion of Dieffenbachia plant (Dumb Cane). Indian Pediatrics 49: $247-248$.

Akça H, Polat E, Tuygun N, Gürcan Kaya N, Karacan CD (2014). Hazard at home: Dieffenbachia. Journal of Academic Emergency Medicine 5: 107-109.

Akpınar M, Müslehiddinoğlu M, Özcan M, Sarıcı SÜ (2016). Herbal hazard: Dieffenbachia. Journal of Child Health and Illness 59: 21-23.

Balabanlı C, Albayrak S, Türk M, Yüksel O (2006). Some toxic plants growing in rangelands of Turkey and their effects on animals. Süleyman Demirel Üniversitesi Orman Fakültesi Dergisi A(2): 89-96.

Barnes BA, Fox LE (1955). Poisoning with "Dieffenbachia". Journal of the History of Medicine and Allied Sciences 10: 173-181.

Cote GG (2009). Diversity and distribution of idioblasts producing calcium oxalate crystals in Dieffenbachia seguine (Araceae). American Journal of Botany 96(7): 1245-1254.

Cumpston KL, Vogel SN, Leikin JB, Erickson TB (2003). Acute airway compromise after brief exposure to a Dieffenbachia plant. The Journal of Emergency Medicine 25(4): 391-397.

Dip EC, Pereira NA, Fernandes PD (2004). Ability of eugenol to reduce tongue edema induced by Dieffenbachia picta Schott in mice. Toxicon 43(6): 729-735.

Faydaoğlu E, Sürücüoğlu MS (2013). Medical and aromatic plants’ antimicrobial, antioxidant activities and use opportunities. EÜFBED - Fen Bilimleri Enstitüsü Dergisi 6(2): 233-265.

Fochtman FW, Manno JE, Winek CL, Cooper JA (1969). Toxicity of the genus Dieffenbachia. Toxicology and Applied Pharmacology 15(1): 38-40.

Gardner DG (1994). Injury to the oral mucous membranes caused by the common houseplant, Dieffenbachia: A review. Oral Surgery, Oral Medicine, Oral Pathology 78(5): 631-633.

Gül V (2014). A general view to medicinal and aromatic plants belonging to rize province. Iğdır Univ. J. Inst. Science and Technology 4(4): 97-107.

Hsueh KF, Lin PY, Lee SM, Hsieh CF (2004). Ocular injuries from plant sap of genera Euphorbia and Dieffenbachia. Journal of Chinese Medicine Assoc 67: 93-98.

Loretti AP, da Silva Ilha MR, Ribeiro RE (2003). Accidental fatal poisoning of a dog by Dieffenbachia picta (dumb cane). Veterinary and Human Toxicology 45(5): 233-239.

Müller N, Glaus T, Gardelle O (1998). Extensive stomach ulcers due to Dieffenbachia intoxication in a cat. Tierarztl Prax ausg K Kleintiere heimtiere 26: 404-407.

Özbek H (2005). Phytotherapy and its use in sexual and gynecological disorders. Van Medical Journal 12(2): 170-174.

Peterson K, Beymer J, Rudloff E, O'Brien M (2009). Airway obstruction in a dog after Dieffenbachia ingestion. Journal of Veterinary Emergency and Critical Care (San Antonio) 19(6): 635-639.

Porsuk AÖ, Cerit Ç, Dönmez A (2014). Dieffenbachia poisoning case. Proceedings of $17^{\text {th }}$ National Public Health Congress, Edirne 2014. Pp. 710-711.

Sıcak Y, Çolak ÖF, İlhan V, Sevindik E, Alkan N (2013). Some medicinal and aromatic plants used commonly among the public in köyceğiz region. Journal of Anatolian Natural Sciences 4(2): 70-77.

Sinajdaufa, J., Mixa, V., Rygl M., Vyhnanek, M., Moravek, J. ve Kabelka, Z.,2005. Aortoesophageal fistula-an unusual complication of esophagitis caused by Dieffenbachia ingestion. Journal of Pediatric Surgery 40: 29-31.

Şişmanlar T, Onganla, YH, Derinöz O, Kula S, Kanbur SM, Vurallı D (2010). GREEN dangers at home: "Dieffenbachia Intoxication', Gazi Medical Journal 21(1): 51-52.

T.C. Sağlık Bakanlığı (2007). Bitkilerle Zehirlenmeleri. In: Tunçok Y, Kalyoncu NI (ed.) Birinci basamağa yönelik zehirlenmeler tan1 ve tedavi rehberleri 2007. Pp: 171-184.

Yilmaz H, Akpınar E, Yılmaz H (2006). Toxicological characteristics of some ornamental plants used in landscape architecture. Süleyman Demirel University Journal of Forestry Faculty A(1): 82-95.

Yilmaz H, Akpınar E, Irmak MA, Yılmaz H (2007). Toxicological properties of ornamental plants used in living areas and the public's concern. Proceedings of TMMOB 3rd Landscape Architecture Congress, Antalya 2007. Pp: 561-572. 